\section{DiscoverSys \\ Published by DiscoverSys \\ Factors affecting the use of electronic cigarettes in Udayana University students}

\author{
Luh Pitriyanti, ${ }^{1 *}$ Dewa Nyoman Wirawan, ${ }^{2}$ Komang Ayu Kartika Sari, ${ }^{2}$ \\ I Made Ady Wirawan, ${ }^{2}$ Desak Putu Yuli Kurniati²
}

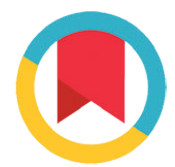

CrossMark

\title{
ABSTRACT
}

Background and purpose: Electronic cigarettes (e-cigarettes) have been marketable since 2003 and first became for sale in Indonesia in 2010. Users tend to be predominately young people. The purpose of this study is to determine the proportion, characteristics and factors that influence the use of e-cigarettes among university students. Methods: This study used a cross sectional survey with 351 undergraduate students from a variety of study programs at Udayana University. Students were selected by multistage random sampling. In the first step, 10 out of 47 study programs at Udayana University were chosen randomly. Students who responded by filling out online questionnaires were included in this study. Data collection was conducted using questionnaires with the Survey Monkey Application. Analysis with logistic regression was applied to determine the factors influencing e-cigarettes use.

Results: The proportion of university students who used tobacco cigarettes was $14.53 \%$. The number of respondents who reported had ever used e-cigarettes was 61 (17.38\%, 95\%Cl: 13.46\%-21.3\%) and 25 of them (40.98\%) were current smokers. As many as $88.52 \%$ of respondents who had ever used e-cigarettes were male and
$11.48 \%$ were female. Students who had ever used e-cigarettes in the campus area were $22(36.07 \%)$. The reasons of using e-cigarettes included a desire to stop using tobacco cigarettes $(29.51 \%)$, the fact that e-cigarettes are considered safer (26.23\%), are considered "cool" (22.95\%) and other reasons (26.23\%). Multivariate analysis showed that the variables found to be associated with the use of e-cigarettes were gender ( $A O R=14.72 ; 95 \% \mathrm{Cl}: 4.34-49.87)$, a history of smoking tobacco cigarettes ( $A O R=42.16 ; 95 \% \mathrm{Cl}: 13.56-131.08)$, a history of consuming alcoholic beverages ( $A O R=5.72 ; 95 \% \mathrm{Cl}$ : $2.04-16.04)$ and coming from a smoking household (AOR=3.87; 95\%Cl: 1.33-11.21).

Conclusion: The proportion of university students who had ever used e-cigarettes was found to be higher than tobacco cigarettes users. In addition, use was found to be greater among male students than females. Influencing factors associated with the use of e-cigarettes are gender, a history of tobacco smoking, a history of consuming alcoholic beverages and coming from a smoking household. There is a need for prevention efforts including education and regulations to reduce the use of e-cigarettes among students as well as community in general.
${ }^{1}$ Denpasar City Health Office, ${ }^{2}$ Department of Public Health and Preventive Medicine, Faculty of Medicine, Udayana University

${ }^{*}$ Correspondence to:

Luh Pitriyanti, Denpasar City Health Office

luhpitriyanti92@gmail.com

Keywords: electronic smoking behaviors, tobacco, university students, Indonesia

Cite This Article: Pitriyanti, L., Wirawan, D.N., Sari, K.A.K., Wirawan, I.M.A., Kurniati, D.P.Y. 2018. Factors affecting the use of electronic cigarettes in Udayana University students. Public Health and Preventive Medicine Archive 6(2): 88-92. D01:10.15562/phpma.v6i2.42

\section{INTRODUCTION}

Electronic cigarettes (e-cigarettes) were first discovered in 1963 by Herbert A. Gilbert. ${ }^{1}$ In 2003 e-cigarettes were produced in more marketable way by a Chinese inventor named Hon Lik. ${ }^{2}$ In 20062007 e-cigarettes were introduced in America and Europe. ${ }^{2}$ The popularity of e-cigarettes continues to increase due to the availability of variations in device technology, size, color, flavor, battery capacity and others. $^{3}$ The World Health Organization (WHO) reported that in 2014 there were 466 varieties of e-cigarettes brands. ${ }^{4}$ Consumption of e-cigarettes is reported to be on the increase in Britain and reported to be as many as 700,000 people in 2012, 1,300,000 in 2013, 2.1 million in 2014 and 2.6 million in $2015 .^{5}$

E-cigarettes were introduced to Indonesia in 2010 and after that the sales of e-cigarettes in Indonesia tended to increase, especially online. ${ }^{6}$ Studies on the use of e-cigarettes have not been widely conducted in Indonesia nor in other countries. This study aims to identify the proportion and factors determining of e-cigarettes usage among Udayana University students, Denpasar, Bali.

\section{METHODS}

A cross sectional survey was conducted using an online questionnaire through the Survey Monkey Application. The number of samples was calculated based on a confidence level of 95\%, power of $80 \%$, proportion of e-cigarettes smokers living with parents or partner who smoke of $25 \%$ and proportion of e-cigarettes smokers who not living with parents or partner who smoke of $16 \%{ }^{7}$

Students were selected by multistage random sampling. In the first step 47 study programs in Udayana University were divided into two groups: 26 science and technology and 21 social science and humanities. From each group, 5 study programs were selected randomly. The selected study programs are presented in Table 1. The number of students who responded by filling out online questionnaire was 351 . 
Data collected via the questionnaire link which was shared through the student executive board of each study program. In order to increase the

Table 1 Number of respondents and response rate by study program

\begin{tabular}{lccc}
\hline Study program & $\mathbf{n}(\%)$ & $\begin{array}{c}\text { Number of } \\
\text { students }\end{array}$ & Response rate (\%) \\
\hline Public Health & $66(18.8)$ & 313 & 21.1 \\
English Language & $20(5.7)$ & 934 & 2.1 \\
Veterinary Science & $29(8.3)$ & 531 & 5.5 \\
Law & $53(15.1)$ & 2,294 & 2.3 \\
Management & $32(9.1)$ & 1,391 & 2.3 \\
State Administration & $38(10.8)$ & 43 & 88.4 \\
Accountancy & $30(8.6)$ & 1,349 & 2.2 \\
Engineering & $43(12.3)$ & 559 & 7.7 \\
Pharmacy & $33(9.4)$ & 284 & 11.6 \\
Physiotherapy & $7(2.0)$ & 50 & 14.0 \\
Total & $351(100.0)$ & 7,748 & 4.53 \\
\hline
\end{tabular}

Table 2 Characteristics of respondents using e-cigarettes, smoking history and reasons for using e-cigarettes

\begin{tabular}{|c|c|}
\hline Variables & n (\%) \\
\hline \multicolumn{2}{|l|}{ History of tobacco use } \\
\hline Ever used & $51(14.53)$ \\
\hline Never & $300(85.47)$ \\
\hline \multicolumn{2}{|l|}{ History of e-cigarettes use } \\
\hline Ever used & $61(17.38)$ \\
\hline Never & $290(82.62)$ \\
\hline \multicolumn{2}{|l|}{ Still using e-cigarettes } \\
\hline Yes & $25(40.98)$ \\
\hline No & $36(59.02)$ \\
\hline \multicolumn{2}{|l|}{ Gender } \\
\hline Male & $54(88.52)$ \\
\hline Female & $7(11.48)$ \\
\hline \multicolumn{2}{|l|}{ Use of e-cigarettes on campus } \\
\hline Yes & $22(36.07)$ \\
\hline No & $39(63.93)$ \\
\hline \multicolumn{2}{|l|}{ Reason for using e-cigarettes ${ }^{\star}$ ) } \\
\hline Deemed safer & $16(26.23)$ \\
\hline Cheaper & $1(1.64)$ \\
\hline Easier to use & $4(6.56)$ \\
\hline Assist with quitting tobacco & $18(29.51)$ \\
\hline Influenced by friends & $7(11.47)$ \\
\hline Deemed prestigious & $14(22.95)$ \\
\hline Other (fun, curiosity, experiment etc) & $16(26.23)$ \\
\hline
\end{tabular}

*) Respondents may choose more than one option number of students who willing to participate in the study, it was announced through broadcast with compensation provided randomly for 40 students in the form of phone credit amounting to IDR 25,000. Data collected included date of birth, gender, domicile, origin, division, cluster, history and access of e-cigarettes, knowledge, history of using tobacco cigarettes, history of consuming alcoholic beverages, living at home with parents, influenced by peers who smoke, and the amount of allowance given by parents every month.

Data were analysed using STATA SE 12.1. Multivariate data analysis was applied using logistic regression to find out factors associated with the use of e-cigarettes. This study has been approved by the Ethics Committee of Faculty of Medicine, Udayana University/Sanglah General Hospital in Denpasar on July 14, 2017.

\section{RESULTS}

Table 1 presents the number of respondents, the number of students in each study program and the response rate. There were 351 students who completed the questionnaire with the overall response rate of $4.53 \%$. The highest response rate was the State Administration Study Program (88.4\%) while the lowest response rate is found in the English Language Study Program (2.1\%). There were more female respondents $(64.10 \%)$ than males (35.90\%). A total of $37.61 \%$ of respondents were aged between $17-19$ years and $62.39 \%$ were aged between 20-24 years.

Table 2 presents data on the history of tobacco and e-cigarettes use. The proportion of students who used tobacco cigarettes was $14.53 \%$. Respondents who had ever used e-cigarettes were 61 students (17.38\%, 95\%CI: $13.46 \%-21.3 \%)$ and 25 of them (40.98\%) were current smokers. As many as $88.52 \%$ of respondents who had ever used e-cigarettes were male and $11.48 \%$ were female. Students who had ever used e-cigarettes on campus area were 22 (36.07\%). The reasons of using e-cigarettes included a desire to stop using tobacco cigarettes (29.51\%), the fact that e-cigarettes are considered safer (26.23\%), are considered "cool" (22.95\%) and other reasons such as fun, curiosity and to experiment (26.23\%).

Table 3 shows bivariate analysis between the history of e-cigarettes usage with several variables. It appears that the proportion of respondents who had ever used e-cigarettes is significantly higher among male students $(\mathrm{p}<0.01)$, in the group of students with less knowledge of the dangers of electronic/ tobacco cigarettes $(\mathrm{p}<0.01)$, a history of using tobacco cigarettes $(\mathrm{p}<0.01)$, had consumed alcoholic beverages $(\mathrm{p}<0.01)$ and had peers who smoke $(\mathrm{p}<0.01)$. 
Table 3 Difference in proportion of e-cigarettes users based on several variables

\begin{tabular}{|c|c|c|c|}
\hline \multirow[b]{2}{*}{ Variable } & \multicolumn{2}{|c|}{ E-cigarettes use } & \multirow[b]{2}{*}{$\mathbf{p}$} \\
\hline & Ever used & Never & \\
\hline \multicolumn{4}{|l|}{ Gender } \\
\hline Male & $54(42.86)$ & $72(57.14)$ & $<0.01$ \\
\hline Female & $7(3.11)$ & $218(96.89)$ & \\
\hline \multicolumn{4}{|l|}{ Knowledge } \\
\hline Poor & $30(27.27)$ & $80(72.73)$ & $<0.01$ \\
\hline Good & $31(12.86)$ & $210(87.14)$ & \\
\hline \multicolumn{4}{|l|}{ Study program } \\
\hline Social Sciences & $22(13.33)$ & $143(86.67)$ & 0.06 \\
\hline Technical Sciences & $39(20.97)$ & $147(79.03)$ & \\
\hline \multicolumn{4}{|l|}{ Smoking tobacco } \\
\hline Yes & $44(86.27)$ & $7(13.73)$ & $<0.01$ \\
\hline No & $17(5.67)$ & $283(94.33)$ & \\
\hline \multicolumn{4}{|l|}{ Alcohol consumption } \\
\hline Yes & $43(47.78)$ & $47(52.22)$ & $<0.01$ \\
\hline No & $18(6.90)$ & $243(93.10)$ & \\
\hline \multicolumn{4}{|l|}{ Lived with parents } \\
\hline Yes & $33(15.57)$ & $179(84.43)$ & 0.27 \\
\hline No & $28(20.14)$ & $111(79.86)$ & \\
\hline \multicolumn{4}{|l|}{ Lived with smokers } \\
\hline Yes & $34(20.24)$ & $134(79.76)$ & 0.18 \\
\hline No & $27(14.75)$ & $156(85.25)$ & \\
\hline \multicolumn{4}{|l|}{ Had peers who smoke } \\
\hline Yes & $60(21.28)$ & $222(78.72)$ & $<0.01$ \\
\hline No & $1(1.45)$ & $68(98.55)$ & \\
\hline \multicolumn{4}{|l|}{ Allowance (IDR) } \\
\hline$>600,000$ & $36(21.43)$ & $132(78.57)$ & 0.06 \\
\hline$\leq 600,000$ & $25(13.66)$ & $158(86.34)$ & \\
\hline \multicolumn{4}{|c|}{ Ease of e-cigarrette access } \\
\hline Yes & $59(17.35)$ & $281(82.65)$ & 0.94 \\
\hline No & $2(18.18)$ & $9(81.82)$ & \\
\hline Total & $61(17.38)$ & $290(82.62)$ & \\
\hline
\end{tabular}

\begin{tabular}{lccc} 
Table 4 & Adjusted odd ratio of factors that associated with the use of e-cigarettes & \\
\hline Variables & AOR & $\mathbf{9 5 \%} \mathbf{C l}$ & $\mathbf{p}$ \\
\hline $\begin{array}{l}\text { Gender } \\
\quad \text { Female }\end{array}$ & 1.00 & & \\
$\quad$ Male & 14.72 & $4.34-49.87$ & $<0.01$ \\
$\begin{array}{l}\text { Knowledge of risks } \\
\quad \text { Good }\end{array}$ & 1.00 & & \\
$\quad \begin{array}{l}\text { Poor } \\
\text { Study program }\end{array} \quad 1.35$ & $0.49-3.72$ & 0.56 \\
$\quad \begin{array}{l}\text { Technical Science } \\
\text { Social Science }\end{array}$ & 1.00 & & \\
& 0.57 & $0.19-1.66$ & 0.30 \\
\hline
\end{tabular}


Table 4 Continue

\begin{tabular}{|c|c|c|c|}
\hline Variables & AOR & $95 \% \mathrm{Cl}$ & $\mathbf{p}$ \\
\hline \multicolumn{4}{|c|}{ History of tobacco use } \\
\hline No & 1.00 & & \\
\hline Yes & 42.16 & $13.56-13.08$ & $<0.01$ \\
\hline \multicolumn{4}{|c|}{ History of alcohol use } \\
\hline No & 1.00 & & \\
\hline Yes & 5.72 & $2.04-16.04$ & 0.01 \\
\hline \multicolumn{4}{|c|}{ Had family members that smoke } \\
\hline No & 1.00 & & \\
\hline Yes & 3.87 & $1.33-11.21$ & 0.01 \\
\hline \multicolumn{4}{|c|}{ Had peers that smoke } \\
\hline No & 1.00 & & \\
\hline Yes & 3.54 & $0.33-37.68$ & 0.29 \\
\hline \multicolumn{4}{|c|}{ Allowance (IDR) } \\
\hline$\leq 600,000$ & 1.00 & & \\
\hline$>600,000$ & 2.02 & $0.74-5.48$ & 0.17 \\
\hline
\end{tabular}

Table 4 presents the results of multivariate analysis with logistic regression to determine the relationship between the use of e-cigarettes with several variables. In this analysis, the variables with $\mathrm{p} \leq 0.25$ in the bivariate analysis were applied. It appears that the variables significantly associated with the use of e-cigarettes were gender (AOR=14.72;95\%CI: 4.34-49.87), a smoking history with tobacco cigarettes $(\mathrm{AOR}=42.16$; 95\%CI: 13.56 131.08), a history of consuming alcoholic beverages $(\mathrm{AOR}=5.72 ;$ 95\%CI: 2.04-16.04) and coming from a smoking household $(\mathrm{AOR}=3.87 ; 95 \% \mathrm{CI}$ : 1.33-11.21).

\section{DISCUSSION}

The proportion of students who had ever used e-cigarettes was $17.38 \%$ (95\%CI: $13.46 \%-21.3 \%$ ) and 25 of them $(40.98 \%)$ were current smokers. In this study, the proportion of male students who reported ever smoking was much higher than female students, which were $42.86 \%$ and $3.11 \%$ respectively. The proportion of students who use e-cigarettes is probably greater than our findings because the proportion of female respondents was twice that of male respondents, which were $64.1 \%$ and $35.9 \%$ respectively, while the proportion of smokers was higher among male students. This study indicates that as many as $14.53 \%$ of students aged between 17-24 years reported had ever smoked tobacco. The proportion of the use of tobacco cigarettes in students was also dominated by male students compared to female students, namely $34.13 \%$ and $3.56 \%$. When compared to the
2013 Indonesia Basic Health Research (Riskesdas) in Bali Province ${ }^{7}$ where it was documented that the proportion of 15-19 year-olds who smoked tobacco every day was $8.2 \%$ and the age of $20-24$ years was $21.8 \%$, the proportion of students who had smoked tobacco was probably about the same as smokers of tobacco in the population of Bali Province aged between 15-24 years. The proportion of 17-24 year old male students who had ever smoked electronics (42.86\%) was found to be higher than the proportion of male population of all ages in Bali Province who were currently smoking tobacco at the time of the Riskesdas. ${ }^{8}$

The proportion of e-cigarettes smokers at Udayana University is found to be similar to findings from a survey conducted in Poland during 2010-2011, wherein among 13,787 15-24 year olds, those that reported who ever smoking e-cigarettes accounted for $20.9 \%$ (95\%CI: 20.1-21.6) and those that were habitual electronics smokers was reported at $6.9 \%$ (95\%CI: 6.4-7.4). ${ }^{7}$ However, the number of female smoking e-cigarettes reported in the study was much higher at $18.8 \%$, compared to survey results from Udayana University.

The main reason of students to use e-cigarettes was a motivation to quit smoking tobacco. Other reasons were the assumption that e-cigarettes are safer, for fun, curiosity and experimental reasons. Similar reasons were reported in a study of college students in France, for example, a motivation to stop using tobacco cigarettes, the better taste of e-cigarettes in comparison with tobacco cigarettes, in order to reduce tobacco cigarette use, to experiment, the cheaper price, in order to avoid 
the risk of tobacco for health and in order to avoid using tobacco cigarettes. ${ }^{9}$

Multivariate analysis indicated that factors related to ever using e-cigarettes were gender, history of using tobacco cigarettes, history of consuming alcoholic beverages as well as coming from a smoking household.

The limitations of our study were the high proportion of female respondents and the survey conducted only among university students. Further study is needed with more representative samples including surveys among the general population.

\section{CONCLUSION}

The proportion of Udayana University students who had ever used e-cigarettes is quite high and the proportion is higher than tobacco smokers. The use was discovered not only among male students but also among female students. Factors associated with the use of e-cigarettes were gender, a history of tobacco smoking, a history of consuming alcoholic beverages and coming from a smoking household. Considering the health and social impacts of e-cigarettes use, prevention measures, both education and regulatory, need to be implemented not only in the campus contexts but also among the general population.

\section{ACKNOWLEDGEMENT}

We would like to thank the President (Rector) of Udayana University, student executive body, student associations, all respondents and other parties who assisted the implementation of this study.

\section{REFERENCES}

1. Gilbert HA. Smokeless non-tobacco cigarette. United States. 1963. Available from: https://patents.google.com/ patent/US3200819A/en.Cited 10 January 2018

2. Sleight VJ. A brief history of the electronic cigarette. Journal of Lung, Pulmonary, Respiratory Research. 2016; 3(5): 5-6.

3. Food and Drug Monitoring Agency. Bahaya rokok elektronik racun berbalut teknologi. [The dangers of electronic cigarette toxic wrapped in technology]. InfoPOM. 2015; pp. 1-12.

4. World Health Organization. Electronic nicotine delivery systems. Conference of the parties to the WHO Framework Convention on Tobacco Control. 2014. Moscow. Available from: http://apps.who.int/gb/fctc/PDF/cop6/FCTC_ COP6_10Rev1-en.pdf?ua=1.Cited 8 January 2018

5. Action on Smoking and Health. Use of e-cigarettes (vapourisers) among adults in Great Britain. Available from: http://ash.org.uk/information-and-resources/ fact-sheets/use-of-e-cigarettes-among-adults-in-greatbritain-2017/.2017. Cited 23 July 2017.

6. Sari TF. Pengaruh dimensi komunitas merek terhadap word of moutt pada rokok elektrik (vapor) merek tesla invader di Bandar Lampung (studi pada komunitas vape squad Lampung) (Skripsi) [The influence of the brand community dimension on word of moutt on electric cigarette (vapor) brand tesla invader in Bandar Lampung (study on Lampung vape squad community) (Thesis)]. Bandar Lampung: Economics and Business Faculty, Lampung University; 2017.

7. Goniewicz ML, Zielinska-Danch W. Electronic cigarette use among teenagers and young adults in Poland. Pediatrics 2012; 130(4): 879-885.

8. Ministry of Health of Indonesia. Riset Kesehatan Dasar (Riskesdas) [Indonesia Basic Health Research]. Jakarta: Ministry of Health of Indonesia; 2013.

9. Tavolacci MP, Vasiliu A, Romo L, Kotbagi G, Kern L, Ladner J. Patterns of electronic cigarette use in current and ever users among college students in France : a crosssectional study. BMJ Open. 2016; 6(5): 1-10.

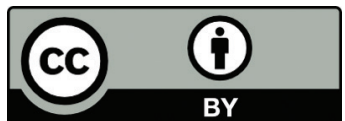

This work is licensed under a Creative Commons Attribution 